\title{
Molecular and kinetic characterization of glutamate synthase from the phototrophic bacterium Rhodobacter capsulatus E1F1
}

\author{
M. Isabel Igeño, Francisco J. Caballero and Francisco Castillo* \\ Departamento de Bioquímica y Biología Molecular, Facultad de Ciencias, Universidad de Córdoba, \\ 14071 Córdoba, Spain
}

(Received 29 March 1993; revised 16 June 1993; accepted 27 July 1993)

\begin{abstract}
Glutamate synthase (GOGAT) from the phototrophic non-sulphur purple bacterium Rhodobacter capsulatus E1F1 has been purified to electrophoretic homogeneity by affinity chromatography. The native protein consisted of two different subunits of 175 and $53 \mathrm{kDa}$ and contained $4 \mathrm{~mol} \mathrm{FAD}, 4 \mathrm{~mol}$ iron and $4 \mathrm{~mol}$ labile sulphide per mol of dimer enzyme. The enzyme used NADPH as the electron donor and was inhibited by iron-chelating and thiol group reagents. GOGAT exhibited NAD(P)H-diaphorase activity which used sodium ferricyanide, cytochrome $c$ and dichlorophenol indophenol as alternative electron acceptors. By contrast, glutaminase activity was not detected in purified GOGAT. The amino acid composition was quite different from that of other bacterial GOGATs, and the protein presented different aggregation states depending on the ionic strength. Two major multimeric active species with Stokes' radii of 6.18 and $7.32 \mathrm{~nm}$ could be separated by gel-filtration of protein solutions made in $0.5 \mathrm{M}-\mathrm{KCl}$, whereas in the absence of salt, the maximal GOGAT activity corresponded to an oligomer with Stokes' radius of $6.80 \mathrm{~nm}$. The enzyme exhibited apparent negative cooperativity for glutamine, and was competitively inhibited by L-glutamate and NADP ${ }^{+}$.
\end{abstract}

\section{Introduction}

Glutamate synthase (GOGAT) was first described by Tempest et al. (1970) as a key enzyme in ammonia assimilation by bacteria, and was later found in other organisms (Lea \& Miflin, 1975; Miflin \& Lea, 1976; Stewart et al., 1980). The enzyme catalyses the reductive transfer of the amide group of L-Gln to 2-oxoglutarate, forming L-Glu:

$$
\begin{aligned}
\mathrm{L}-\mathrm{Gln}+2 \text {-oxoglutarate }+\mathrm{NAD}(\mathrm{P}) \mathrm{H}+\mathrm{H}^{+} \rightarrow & 2 \mathrm{~L}-\mathrm{Glu} \\
& +\mathrm{NAD}(\mathrm{P})^{+}
\end{aligned}
$$

The enzyme has been purified and characterized from eubacteria including Escherichia coli (Miller \& Stadtman, 1972), Azospirillum brasilense (Ratti et al., 1985) and Aerobacter aerogenes (Trotta et al., 1974). The active enzyme is composed of a small subunit of relatively constant molecular mass (about $50 \mathrm{kDa}$ ) and a large subunit of molecular mass ranging from $135 \mathrm{kDa}$

\footnotetext{
*Author for correspondence.

Abbreviations: DCPIP, dichlorophenol indophenol; DTE, dithioerythritol; GOGAT, glutamate synthase; GS, glutamine synthetase; MSX, L-methionine DL-sulphoximine; pHMB, 4-(hydroxymercuri) benzoate.
}

(E. coli; Miller \& Stadtman, 1972) to $200 \mathrm{kDa}$ (Thiobacillus thioparus; Adachi \& Suzuki, 1977). GOGATs from bacteria are iron-sulphur flavoproteins, with the exception of that of Clostridium pasteurianum, which apparently possesses a different quaternary structure and lacks iron and flavin as prosthetic groups (Singhal et al., 1989). There have been only a few reports containing partial characterizations of GOGAT from phototrophic bacteria (Yelton \& Yoch, 1981; Caballero et al., 1989b; Carlberg \& Nordlund, 1991).

The phototrophic nonsulphur purple bacterium Rhodobacter capsulatus E1F1 reduces inorganic nitrogen to ammonium which, as in other Rhodospirillaceae strains, is assimilated to nitrogen compounds through the glutamine synthetase (GS)/GOGAT cycle (Johansson \& Gest, 1976; Alef \& Zumft, 1981; Caballero et al., 1985). When the bacterium is grown with reduced nitrogen compounds, ammonium is incorporated into carbon skeletons by an alternative pathway which includes L-alanine dehydrogenase and L-alanine:2-oxoglutarate aminotransferase activities (Moreno-Vivián et al., 1983; Caballero et al., 1989a; Moreno-Vivián et al., 1990). This alternative pathway is also induced in L-methionine DL-sulphoxime (MSX)-treated bacterial cells, which have an inactivated GS (Moreno-Vivián et al., 1983; Romero et al., 1985). As described for other Rhodospirillaceae 
strains (Johansson \& Gest, 1976; Herbert et al., 1978; Madigan \& Cox, 1982), $R$. capsulatus E1F1 lacks glutamate dehydrogenase activity. An apparent glutamate dehydrogenase activity observed in crude extracts of $R$. capsulatus E1F1 was actually due to the coupling of L-alanine: 2-oxoglutarate aminotransferase and L-alanine dehydrogenase activities (Castillo et al., 1991). This L-alanine dehydrogenase has been purified and characterized at the molecular level (Caballero et al., 1989a).

Although GS from phototrophic bacteria has been exhaustively characterized (Alef \& Zumft, 1981; Nordlund et al., 1985; Caballero et al., 1985, 1987), less is known of GOGAT. GOGAT has been purified and partially characterized only from Rhodospirillum rubrum (Yelton \& Yoch, 1981; Carlberg \& Nordlund, 1991), a phototrophic bacterium which is not very closely related to $R$. capsulatus as deduced from $16 \mathrm{~S}$ rRNA sequence analysis (Woese, 1987). GOGATs from heterotrophic bacteria are well-studied, dimeric enzymes of similar structural properties, quaternary structure and subunit size (Miller \& Stadtman, 1972; Trotta et al., 1974; Schreier \& Bernlohr, 1984; Ratti et al., 1985). By contrast, GOGATs from photosynthetic eukaryotic organisms are composed of a single polypeptide chain which has an unusually high molecular mass of 150 $200 \mathrm{kDa}$ (Galván et al., 1984; Avila et al., 1987). The large subunit from the GOGAT of $A$. aerogenes has been isolated and exhibits both glutaminase and NADPH oxidase activities (Trotta et al., 1974). This subunit also contains flavin and non-haem iron in E. coli (Mäntsälä \& Zalkin, 1976a) and seems to catalyse $\mathrm{NH}_{4}^{+}$-dependent L-glutamate synthesis. In addition, bacterial GOGATs exhibit several aggregation states depending on ionic strength (Miller \& Stadtman, 1972; Yelton \& Yoch, 1981; Carlberg \& Nordlund, 1991). In E. coli, two structural genes, glt $B$ and $g l t D$, form an operon with a regulatory gene, gltF (Castaño et al., 1988). The reaction mechanism of GOGAT has been extensively studied in E. coli (Mäntsälä \& Zalkin, $1976 a, b$ ) and $A$. brasilense (Ratti et al., 1987; Vanoni et al., 1990, $1991 a, b$, 1992).

Glutamate biosynthesis and utilization in diazotrophic bacteria constitute a metabolic branch point with regulatory significance controlling glutamine concentration (and therefore the intracellular $\mathrm{C} / \mathrm{N}$ balance) as well as several biochemical pathways related to the production of osmolytes (Madkour et al., 1990). GOGAT from Rsp. rubrum has been proposed as being involved in regulating nitrogenase activity (Carlberg \& Nordlund, 1991). $R$. capsulatus ElF1 is a moderate halophilic diazotroph whose nitrogenase, nitrate reductase and GS seem to be controlled by $\mathrm{C} / \mathrm{N}$ status (Moreno-Vivián et al., 1990). Unlike GS, GOGAT from phototrophic bacteria is not regulated through an interconversion mechanism, although enzyme synthesis does increase in the presence of glutamine (Caballero et al., 1989 b).

This work presents the characterization of an enzyme with an unusual prosthetic group composition with respect to other bacterial GOGATs. We have also studied the kinetic parameters of the enzyme, which can be related to a possible regulatory role of GOGAT at the confluence of carbon and nitrogen fluxes in bacterial metabolism.

\section{Methods}

Organism and growth conditions. Rhodobacter capsulatus E1F1 was cultured phototrophically with DL-malate as the carbon source and L-glutamine as the nitrogen source, as described previously (Caballero et al., 1989b).

Purification of GOGAT. All purification steps were performed at $4{ }^{\circ} \mathrm{C}$. (i) Cell extracts. Cells were harvested at the mid-exponential phase of growth by centrifugation at $20000 \mathrm{~g}$ for $15 \mathrm{~min}$, washed with $50 \mathrm{~mm}-\mathrm{MOPS} / \mathrm{KOH}$ buffer ( $\mathrm{pH} \mathrm{7.5)}$, and resuspended in the same buffer containing $2.5 \%(\mathrm{v} / \mathrm{v})$ glycerol and $2 \mathrm{~mm}$-DTE (buffer A). Cell suspensions were sonicated in a Vibracell sonifier $(20 \times 5 \mathrm{~s}$ at $90 \mathrm{~W})$ and, after centrifugation of sonicated cells at $15000 \mathrm{~g}$ for $15 \mathrm{~min}$, the supernatant was further clarified by ultracentrifugation at $100000 \mathrm{~g}$ for $90 \mathrm{~min}$ to eliminate the chromatophore fraction. The clear supernatant was used as the starting material for enzyme purification.

(ii) Ammonium sulphate precipitation. Ammonium sulphate (194 $\mathrm{mg} \mathrm{ml}^{-1}$ ) was added to the cell extract with constant stirring for $20 \mathrm{~min}$ to bring it to $35 \%$ saturation. The solution was allowed to stand for $15 \mathrm{~min}$ and then centrifuged at $36000 \mathrm{~g}$ for $15 \mathrm{~min}$. The pellet was discarded and the supernatant adjusted to $50 \%$ ammonium sulphate saturation by adding $87 \mathrm{mg} \mathrm{ml}^{-1}$. After $15 \mathrm{~min}$ stirring, the solution was allowed to stand for $15 \mathrm{~min}$ and then centrifuged as above; the pellet, containing most of the enzyme activity, was resuspended in a minimal volume of buffer $\mathrm{A}$.

(iii) First gel-filtration. The $35-50 \%$ saturated ammonium sulphate fraction was applied to a Sephacryl S-300 HR column $(100 \times 2.6 \mathrm{~cm})$ equilibrated with buffer A. Proteins were eluted with the same buffer at a flow rate of $50 \mathrm{ml} \mathrm{h}^{-1}$, and fractions containing GOGAT activity were pooled.

(iv) Affinity chromatography. The pooled fractions from Sephacryl chromatography were passed through a Red-120 agarose $(22 \times 1.6 \mathrm{~cm})$ column equilibrated with buffer A. After washing with the same buffer A containing $0 \cdot 1 \mathrm{M}-\mathrm{KCl}$, GOGAT activity was eluted by using a linear gradient of $100 \mathrm{ml} 0 \cdot 1-0.5 \mathrm{M}-\mathrm{KCl}$.

(v) Second gel-filtration. Fractions containing enzyme activity were pooled and concentrated by adding solid ammonium sulphate up to $60 \%$ saturation $\left(361 \mathrm{mg} \mathrm{ml}^{-1}\right.$ ). The pellet was resuspended in an appropriate volume of buffer $\mathrm{A}$ and a concentrated solution was applied to a Sephacryl S-300 HR column $(90 \times 1.6 \mathrm{~cm})$ previously equilibrated with the same buffer at a flow rate of $50 \mathrm{ml} \mathrm{h}^{-1}$.

(vi) Anion-exchange chromatography. Pooled active fractions from step (v) were applied to a DEAE-Sephacel column $(6 \times 1.7 \mathrm{~cm})$ equilibrated with buffer A. After washing with $20 \mathrm{ml}$ of the same buffer, the enzyme was eluted with $100 \mathrm{ml}$ of a linear gradient of $0-0.5 \mathrm{M}-\mathrm{KCl}$ in buffer $\mathrm{A}$ at a flow rate of $25 \mathrm{ml} \mathrm{h}^{-1}$. Fractions containing GOGAT activity were pooled and concentrated by ultrafiltration in Centricon30 vials (Amicon).

Enzyme activities. Glutamate synthase [L-glutamate: NADP ${ }^{+}$ oxidoreductase (transaminating); EC 1.4.1.13] activity was determined spectrophotometrically at $340 \mathrm{~nm}$ as previously described 
(Caballero et al., 1989b). Diaphorase activity was measured spectrophotometrically in purified preparations by following the oxidation rate of $\mathrm{NAD}(\mathrm{P}) \mathrm{H}$ at $340 \mathrm{~nm}$, as described by Márquez et al. (1984). The reaction mixture contained $\left(\mathrm{ml}^{-1}\right): 100 \mu \mathrm{mol} \mathrm{MOPS} / \mathrm{KOH}$ buffer $(\mathrm{pH} 7.6), 0.3 \mu \mathrm{mol} \mathrm{NAD}(\mathrm{P}) \mathrm{H}, 0.6 \mu \mathrm{mol}$ of electron acceptor. Diaphorase activity was also measured electrophoretically as described by Wang \& Raper (1970).

One unit of enzyme activity is defined as the amount of enzyme which catalyses the disappearance of $1 \mu \mathrm{mol} \mathrm{NAD}(\mathrm{P}) \mathrm{H} \mathrm{min}^{-1}$.

Determination of molecular parameters. Stokes' radius, $\alpha$, and the diffusion coefficient, $D_{20, w}$, were determined (at $4{ }^{\circ} \mathrm{C}$ ) as described by Siegel \& Monty (1966) and Pundak \& Eisenberg (1981), respectively, using a Sephacryl S-300 HR column $(36 \times 2.4 \mathrm{~cm})$ equilibrated with buffer $\mathrm{A}$. The following standards (in $\mathrm{nm}$ and $\mathrm{m}^{2} \mathrm{~s}^{-1} \times 10^{11}$ ) were used: bovine pancreas ribonuclease $(1 \cdot 8 ; 1 \cdot 19)$; bovine serum albumin $(3.55$; $0.59)$; yeast alcohol dehydrogenase $(4.61 ; 0.47)$; bovine liver catalase $(5 \cdot 22 ; 0.41)$; and horse spleen apoferritin $(7 \cdot 8 ; 0.36)$.

The sedimentation coefficient, $s_{20 \text {, w }}$, was obtained by the method of Martin \& Ames (1961) using a linear sucrose gradient (5-20\%) at $4{ }^{\circ} \mathrm{C}$. The following standards from Sigma were used (in $\mathrm{S}$ ): horse heart cytochrome $c(1.83)$; bovine serum albumin (4.65); yeast alcohol dehydrogenase $(7.65)$; bovine liver catalase $(11.35)$; horse spleen apoferritin (17.6); and bovine thyroglobulin (19.45).

The relative frictional quotient, $f / f_{0}$, was calculated according to Brewer et al. (1974).

Electrophoresis. Non-denaturing- and SDS-PAGE were performed as described previously (Laemmli, 1970). For determination of the molecular mass of GOGAT subunits, the following standards from Sigma were used (in $\mathrm{kDa}$ ): bovine erythrocyte carbonic anhydrase (29); rabbit muscle glyceraldehyde-3-phosphate dehydrogenase (36); egg albumin (45); bovine serum albumin (66); rabbit muscle phosphorylase b (97.4); E. coli $\beta$-galactosidase (116); and rabbit muscle myosin (205).

Amino acid composition. The amino acid analysis of purified GOGAT was carried out in a Waters HPLC, using the Waters PICO-TAG method, after hydrolysis in $6 \mathrm{M}-\mathrm{HCl}$ by a standard procedure. Tryptophan was determined after alkaline hydrolysis with $4 \mathrm{M}-\mathrm{NaOH}$.

Analytical procedures. Protein was routinely estimated according to Bradford (1976) with bovine serum albumin as a standard. When necessary, the values of protein content were also obtained by the Lowry method and by the method of Smith et al. (1985).

Flavin content was determined in pure enzyme preparations, after thermal deproteinization, by analysing the emission fluorescence spectrum in a Hitachi-Perkin-Elmer, model $650-40$, spectrofluorimeter. FMN and FAD were identified by a reverse-phase HPLC method. Homogeneous enzyme preparations were heated at $120^{\circ} \mathrm{C}$ in the dark, centrifuged to eliminate coagulated proteins, and the supernatants were injected in a Spheri-5 ODS (Brownlee Laboratories) HPLC column $(5 \mu)$ previously equilibrated with $10 \mathrm{~mm}$-potassium phosphate buffer $(\mathrm{pH} 7 \cdot 0)$. Samples were eluted by using a gradient of $0-50 \%(\mathrm{v} / \mathrm{v})$ methanol in the same phosphate buffer for $20 \mathrm{~min}$ with a flow rate of $1 \mathrm{ml} \mathrm{min}{ }^{-1}$. Either FMN or FAD from Sigma was used as a standard.

The iron content of the purified enzyme was determined according to Doeg \& Ziegler (1962), based on the reaction between $o$-phenanthroline and the $\mathrm{Fe}(\mathrm{II})$ released from the protein after acid treatment.

Labile sulphide was determined by the formation of methylene blue from $N, N$-dimethyl-p-phenylenediamine (Beinert, 1983).

\section{Results and Discussion}

In $R$. capsulatus E1F1, GOGAT was strictly dependent on NADPH as the electron donor and L-glutamine as the nitrogen donor. In contrast to reports on other bacterial
GOGATs (Trotta et al., 1974; Mäntsälä \& Zalkin, $1976 b$; Ratti et al., 1985), the purified enzyme from $R$. capsulatus E1F1 neither used ammonia as nitrogen donor nor showed glutaminase activity. A high $\mathrm{NAD}(\mathrm{P}) \mathrm{H}$-diaphorase activity, which used sodium ferricyanide, $p$-nitro blue tetrazolium, cytochrome $c$ and DCPIP as alternative substrates, is linked to GOGAT in $R$. capsulatus E1F1 (Table 1). It is worth noting that this activity used both pyridine nucleotides as the electron donor, although NADH was considerably less effective. NADH-GOGAT from green algae also exhibits diaphorase activity with $\mathrm{NAD}(\mathrm{P}) \mathrm{H}$ as reductant (Márquez et al., 1984).

The purification of GOGAT from $R$. capsulatus E1F1 is a simple, high-yielding procedure, which includes gelfiltration and affinity and anion-exchange chromatographies (Table 2). The specific activity of the purified fraction was similar to that described for other bacterial GOGATs (Schreier \& Bernlohr, 1984; Ratti et al., 1985; Carlberg \& Nordlund, 1991).

Protein fractions from the DEAE-Sephacel column (step vi of purification) showed two protein bands in SDS-PAGE corresponding to molecular masses of $175 \mathrm{kDa}$ (subunit $\alpha$ ) and $53 \mathrm{kDa}$ (subunit $\beta$ ). When subjected to non-denaturing PAGE, purified preparations were resolved into a major band of $230 \mathrm{kDa}$, exhibiting both diaphorase and GOGAT activities, and a minor protein band corresponding to the large subunit that showed no activity (data not shown); this indicated that the small subunit is essential for both activities.

The molecular masses of the GOGAT subunits from R. capsulatus E1F1 (53 and $175 \mathrm{kDa}$ ) were similar to those of the $A$. aerogenes enzyme (Trotta et al., 1974), whereas GOGATs from $E$. coli, $A$. brasilense and Nocardia mediterranii possess a small subunit of about $50 \mathrm{kDa}$ and a large subunit of about $140 \mathrm{kDa}$ (Miller \& Stadtman, 1972; Ratti et al., 1985; Mei \& Jiao, 1988). A

\section{Table 1. Electron acceptors for the $N A D(P) H$ - diaphorase activity of GOGAT from $R$. capsulatus EIFI}

Diaphorase activity was determined as indicated in Methods by using NADPH or NADH as electron donor, and the indicated electron acceptor. A purified preparation of 21 UGOGAT activity $\mathrm{mg}^{-1}$ was used. Data represent the mean of four experiments.

\begin{tabular}{lcc}
\hline \hline & \multicolumn{2}{c}{ Diaphorase activity $\left(\mathrm{U} \mathrm{mg}^{-1}\right)$} \\
\cline { 2 - 3 } Electron acceptor & NADPH & NADH \\
\hline None & 0 & 0 \\
DCPIP & $68.33 \pm 1.07$ & $13.87 \pm 0.72$ \\
Cytochrome $c$ & $10.96 \pm 0.86$ & $11.05 \pm 1.34$ \\
$p$-Nitro blue tetrazolium chloride & $8 \cdot 23 \pm 1.44$ & 0 \\
Ferricyanide & $2 \cdot 37 \pm 0.56$ & 0 \\
\hline
\end{tabular}


Table 2. Purification of GOGAT from $50 \mathrm{~g}$ (fresh weight) of $R$. capsulatus E1FI

Purification steps (i)-(iv) were performed four times on a small scale, using $200 \mathrm{ml}$ of crude extract each time, and the resulting purified fractions pooled and used as starting material for steps (v) and (vi).

\begin{tabular}{|c|c|c|c|c|c|c|}
\hline \multirow[b]{2}{*}{ Purification step } & \multirow[b]{2}{*}{$\begin{array}{l}\text { Vol. } \\
\text { (ml) }\end{array}$} & \multirow[b]{2}{*}{$\begin{array}{c}\text { Protein } \\
(\mathrm{mg})\end{array}$} & \multicolumn{2}{|c|}{ GOGAT activity } & \multirow[b]{2}{*}{$\begin{array}{l}\text { Purification } \\
\text { (-fold) }\end{array}$} & \multirow[b]{2}{*}{$\begin{array}{l}\text { Yield } \\
(\%)\end{array}$} \\
\hline & & & $\begin{array}{c}\text { Specific } \\
\left(\mathbf{U ~ m g}^{-1}\right)\end{array}$ & $\begin{array}{c}\text { Total } \\
\text { (U) }\end{array}$ & & \\
\hline (i) Cell-free extract & 200 & 1160 & 0.05 & 58 & 1 & 100 \\
\hline (ii) Ammonium sulphate (35-50\%) & 18 & 367 & 0.15 & 55 & 3 & 95 \\
\hline (iii) Sephacryl S-300 HR & 82 & 145 & 0.33 & 48 & 7 & 83 \\
\hline (iv) Red-120 agarose & 25 & $7 \cdot 21$ & $5 \cdot 83$ & 42 & 116 & 72 \\
\hline (v) Sephacryl S-300 HR & 30 & $14 \cdot 38$ & $9 \cdot 04$ & 130 & 181 & 56 \\
\hline (vi) DEAE-Sephacel & 7 & $4 \cdot 9$ & $21 \cdot 22$ & 104 & 425 & 45 \\
\hline
\end{tabular}

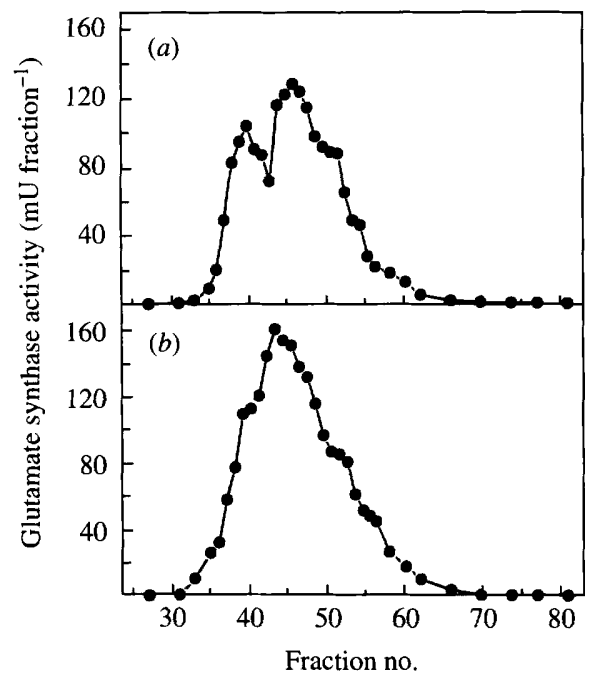

Fig. 1. Effect of $\mathrm{KCl}$ on the aggregation of GOGAT protomers from $R$. capsulatus E1F1. Partially purified GOGAT solutions were passed through a Sephacryl S-300 HR column $(100 \times 1.6 \mathrm{~cm})$ equilibrated with buffer $\mathrm{A}(b)$, or with the same buffer containing $0.5 \mathrm{M}-\mathrm{KCl}(a)$. Fractions $(1.7 \mathrm{ml})$ were collected at a rate of $50 \mathrm{ml} \mathrm{h}^{-1}$.

large subunit of $152 \mathrm{kDa}$ has been reported in GOGAT from Rsp. rubrum (Carlberg \& Nordlund, 1991).

Like GOGATs from other bacteria (Miller \& Stadtman, 1972; Yelton \& Yoch, 1981; Carlberg \& Nordlund, $1991)$, the enzyme from $R$. capsulatus E1F1 exhibited different aggregation states, as deduced from gelfiltration profiles, depending on the ionic strength (Fig. 1). A quaternary structure including a large and a small subunit could be deduced from the molecular mass of the native protein in $R$. capsulatus E1F1 in the absence of $\mathrm{KCl}$, whereas in the presence of salt, different protein superaggregates could be observed (Fig. 1). Thus, two major oligomeric species with Stokes' radii of 7.32 and $6.18 \mathrm{~nm}$ were obtained from Sephacryl S-300 HR filtration of a GOGAT preparation in buffer A containing $0.5 \mathrm{M}-\mathrm{KCl}$ (Fig. 1a). However, in the absence of salt, a major protein peak corresponding to a Stokes' radius of $6.80 \mathrm{~nm}$ could be observed in the Sephacryl S-300 HR eluate (Fig. 1b). Other minor components were also detected in both preparations (Figs $1 a$ and $b$ ). As deduced from the staining for GOGAT and diaphorase activities in non-denaturing polyacrylamide gels, the different superaggregation states were functional. An overestimation of the molecular masses of these oligomeric species was obtained from gel-filtration data due to the high frictional quotient of native GOGAT of $R$. capsulatus E1F1 (1.60) indicative of a non-spherical shape. A more accurate value was obtained from hydrodynamic data of the protein as described by Siegel \& Monty (1966). Thus, a molecular mass of about $243 \mathrm{kDa}$ (quaternary structure $\alpha \beta$ ) for the native protein was estimated by combining data from gel-filtration and sedimentation experiments performed in the absence of $\mathrm{KCl}$ (Table 3). Nevertheless, taking into account a Stokes' radius of $6.80 \mathrm{~nm}$ obtained by filtration of the protein through a Sephacryl S-300 HR column equilibrated in buffer $\mathrm{A}$, a molecular mas of $455 \mathrm{kDa}$ was calculated for GOGAT from $R$. capsulatus E1F1. This may be the correct value if it is assumed that the superaggregate has a spherical shape and a quaternary structure of $\alpha_{2} \beta_{2}$. A quaternary structure of $\alpha_{4} \beta_{4}$ has been reported for GOGATs from $E$. coli (Miller \& Stadtman, 1972) and Rsp. rubrum in $0 \cdot 1-0 \cdot 4 \mathrm{M}-\mathrm{NaCl}$ (Yelton \& Yoch, 1981; Carlberg \& Nordlund, 1991), although the enzyme from Rps. rubrum also exhibits the tetrameric, $\alpha_{2} \beta_{2}$ form (Carlberg \& Nordlund, 1991). Sedimentation coefficients of glutamate synthase from $A$. aerogenes and Bacillus licheniformis (Trotta et al., 1974; Schreier \& Bernlohr, 1984) were higher than that found in the $R$. capsulatus E1F1 enzyme, which could be due to different aggregation states of the protein from these bacteria.

GOGAT from $R$. capsulatus E1F1 is an iron-sulphur flavoprotein which contains $4 \mathrm{~mol} \mathrm{FAD}, 4 \mathrm{~mol}$ iron and 4 mol labile sulphide per mol of enzyme (Table 3 ). The flavin prosthetic group was identified in native purified 
Table 3. Molecular and kinetic parameters of GOGAT from $R$. capsulatus EIFI

\begin{tabular}{|c|c|}
\hline Stokes' radius (nm) & $\begin{array}{l}7 \cdot 32 / 6 \cdot 18^{*} \\
6 \cdot 80^{\dagger}\end{array}$ \\
\hline Sedimentation coefficient, $s_{20, w}(\mathrm{~S})$ & $7 \cdot 6$ \\
\hline Diffusion coefficient, $D_{20 . \mathrm{w}} \times 10^{11}\left(\mathrm{~m}^{2} \mathrm{~s}^{-1}\right)$ & $\begin{array}{l}3 \cdot 4 / 3 \cdot 7^{*} \\
3 \cdot 5 \dagger\end{array}$ \\
\hline Frictional quotient, $f / f_{0}$ & 1.60 \\
\hline \multicolumn{2}{|l|}{ Molecular mass (kDa): } \\
\hline $\begin{array}{l}\text { native enzyme } \\
\text { subunits }\end{array}$ & $\begin{array}{l}228-243 \\
175 \cdot 53\end{array}$ \\
\hline Type of monomer & 2 \\
\hline Number of subunits & 2 \\
\hline Activation energy $\left(\mathrm{kJ} \mathrm{mol}^{-1}\right)$ & $25 \cdot 15$ \\
\hline$Q_{10}\left(25-35^{\circ} \mathrm{C}\right)$ & $1 \cdot 39$ \\
\hline Optimum pH & 7.5 \\
\hline \multicolumn{2}{|l|}{ Apparent $K_{\mathrm{m}}(\mathrm{mm})$ : } \\
\hline NADPH & 0.020 \\
\hline L-GIn & $0 \cdot 45 / 3 \cdot 4$ \\
\hline 2-oxoglutarate & 0.015 \\
\hline Hill coefficient (for L-Gln) & 0.5 \\
\hline Absorption maxima $(\mathrm{nm})$ & $278 ; 372 ; 443$ \\
\hline \multicolumn{2}{|l|}{ Prosthetic groups [mol (mol enzyme $\left.)^{-1}\right]$ : } \\
\hline $\mathrm{Fe}$ & $3 \cdot 9 \pm 0 \cdot 4$ \\
\hline FAD & $3 \cdot 7 \pm 0 \cdot 2$ \\
\hline Labile sulphide & $4 \cdot 1 \pm 0 \cdot 5$ \\
\hline
\end{tabular}

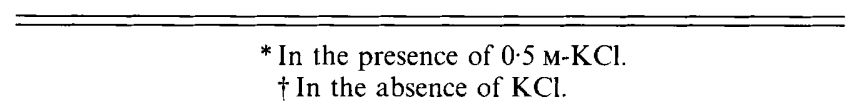

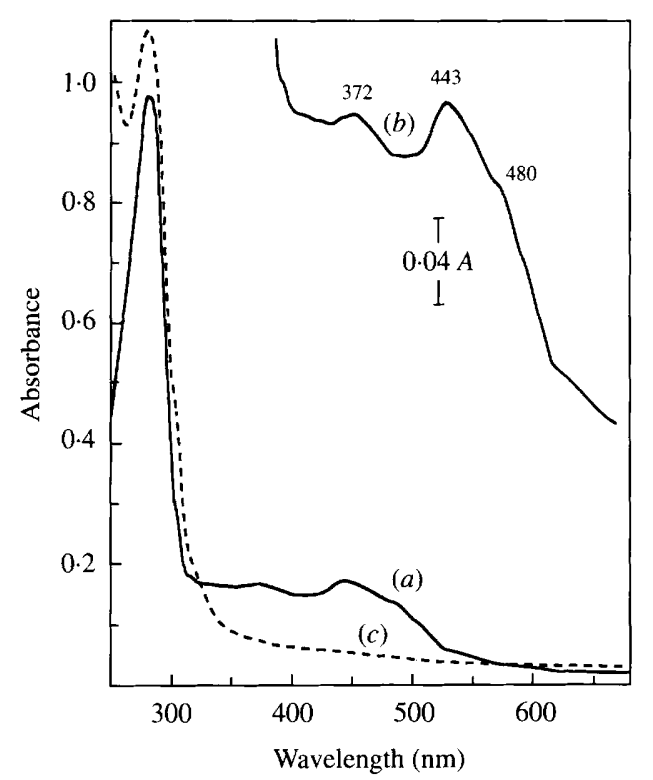

Fig. 2. Photochemical reduction of purified GOGAT from $R$. capsulatus E1Fl. Spectra of the enzyme $\left(0.7 \mathrm{mg} \mathrm{ml}^{-1}\right)$ were recorded anaerobically in buffer A without DTE ( $a$ and $b$ ) or in the same buffer containing $1 \mathrm{~mm}$-EDTA and $5 \mu \mathrm{M}$-5-deazariboflavin $(c)$. (a) Native enzyme; $(b)$ native enzyme in an expanded range; $(c)$ fully reduced enzyme after blue light irradiation.

GOGAT. HPLC chromatograms of boiled purified protein fractions showed peaks with retention times corresponding to FAD, which was also identified by analysing the spectrum of the flavin peak with a diode-

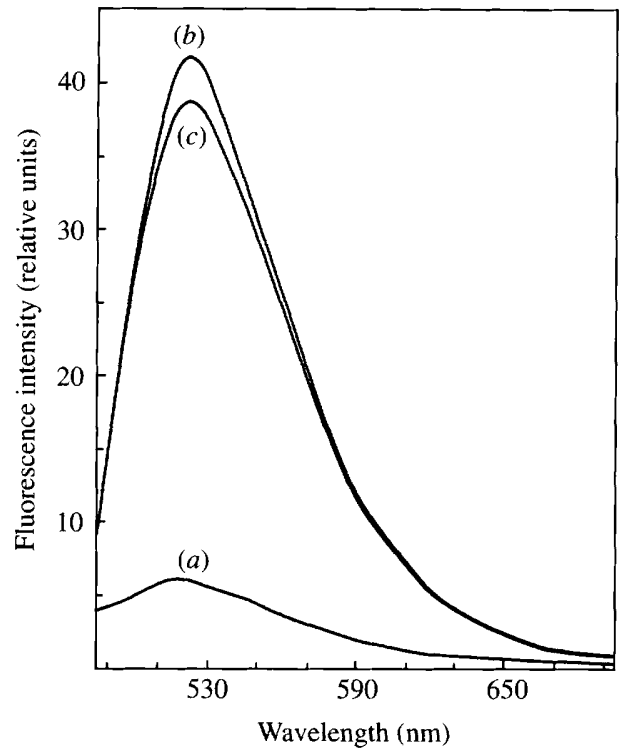

Fig. 3. Fluorescence emission spectra from the flavin component of purified GOGAT from $R$. capsulatus E1F1. Emission spectra were recorded by illuminating the pure enzyme preparations $\left(0.16 \mathrm{mg} \mathrm{m}^{-1}\right)$ with $450 \mathrm{~nm}$ wavelength light. (a) Intact native enzyme; $(b)$ the same after 20 min boiling; $(c)$ the same after 6 M-urea treatment.

array system coupled to the HPLC. An unusual flavin content of 4 mol FAD per mol of enzyme was calculated from fluorimetric studies. This value was also estimated from UV-visible spectroscopic data using an $\varepsilon_{448}$ of $11400 \mathrm{M}^{-1} \mathrm{~cm}^{-1}$ for FAD and an $\varepsilon_{448}$ of $10600 \mathrm{M}^{-1} \mathrm{~cm}^{-1}$ for the iron-sulphur cluster. Figure 2 shows the UVvisible spectra of oxidized and reduced forms of GOGAT. The native oxidized protein showed absorption maxima at 278, 372 and $443 \mathrm{~nm}$ (Fig. 2 and Table 3). The absorption spectrum of GOGAT in the visible region was completely bleached by EDTA/5-deazariboflavin photoreduction under anaerobic conditions. The fluorescence emission at $530 \mathrm{~nm}$ of the native enzyme was considerably enhanced in the denatured enzyme (Fig. 3) probably due to a quenching effect of the apoprotein, as described in B. licheniformis (Schreier \& Bernlohr, 1984).

By contrast, the $A$. aerogenes enzyme contains $1 \mathrm{~mol}$ FAD and 1 mol FMN per mol of enzyme, both located in the large subunit (Trotta et al., 1974). GOGATs from A. brasilense and Rsp. rubrum also possess FAD and FMN as prosthetic groups (Ratti et al., 1985; Carlberg \& Nordlund, 1991). The iron content of the $R$. capsulatus E1F1 enzyme was less than that described in Rsp. rubrum and A. brasilense (Carlberg \& Nordlund, 1991; Ratti et al., 1985). An $A_{278} / A_{443}$ ratio of 5.7 was calculated from the UV-visible spectrum of purified oxidized $R$. capsulatus E1F1 GOGAT. Taking into account that this enzyme contained a high amount of FAD, this $A_{278} / A_{443}$ ratio can be explained on the basis of the high content of tyrosine residues, which could account for a high 
Table 4. Effect of some reagents on the activity of GOGAT from $R$. capsulatus $E 1 F 1$

Purified enzyme was assayed as described in Methods in the presence of the reagents at the indicated concentrations. Other metal chelators such as $\mathrm{CN}^{-}, \mathrm{N}_{3}^{-}, \mathrm{C}_{2} \mathrm{H}_{2}, \mathrm{CO}, \mathrm{NO}, \mathrm{O}_{2}$ were without effect. Percentage inhibition was calculated with respect to control activity in the absence of any added inhibitor $\left(21 \mathrm{U} \mathrm{mg}^{-1}\right)$. Data represent the mean of four experiments.

\begin{tabular}{lcc}
\hline \hline Inhibitor & $\begin{array}{c}\text { Concn } \\
(\mathrm{mM})\end{array}$ & $\begin{array}{c}\text { Inhibition } \\
(\%)\end{array}$ \\
\hline Atebrin & $0 \cdot 2$ & $12 \cdot 21 \pm 1 \cdot 82$ \\
& 0.5 & $27 \cdot 34 \pm 2.08$ \\
Salicylhydroxamate & 1 & $6 \cdot 27 \pm 1.03$ \\
& 10 & $90 \cdot 42 \pm 3.21$ \\
o-Phenanthroline & 1 & $15 \cdot 83 \pm 1.33$ \\
& 10 & $72 \cdot 11 \pm 1.09$ \\
2,2'-Dipyridyl & $0 \cdot 2$ & $22 \cdot 42 \pm 1 \cdot 73$ \\
& 0.5 & $59 \cdot 80 \pm 1.87$ \\
\hline
\end{tabular}

\section{Table 5. Effect of thiol reagents on GOGAT activity of} R. capsulatus E1Fl

Purified enzyme was dialysed to remove DTE present in buffer A. Dialysed enzyme was preincubated for $10 \mathrm{~min}$ in the presence of the reagents at the indicated concentrations, and assayed as described in Methods. To allow complete reactivation of enzyme treated with $\mathrm{pHMB}$, an additional period of $5 \mathrm{~min}$ incubation with DTE was required. Specific activity of $100 \%$ corresponded to $21 \mathrm{U} \mathrm{mg}^{-1}$. Data represent the mean of four experiments.

\begin{tabular}{lcc}
\hline \hline Reagent & $\begin{array}{c}\text { Concn } \\
(\mathrm{mM})\end{array}$ & $\begin{array}{c}\text { Activity } \\
(\%)\end{array}$ \\
\hline Iodoacetate & 1 & $91 \cdot 67 \pm 1 \cdot 29$ \\
& 5 & $88 \cdot 31 \pm 1 \cdot 44$ \\
$N$-Ethylmaleimide & 1 & $39 \cdot 75 \pm 1 \cdot 71$ \\
& 5 & $10 \cdot 38 \pm 2 \cdot 14$ \\
pHMB & $0 \cdot 1$ & $39 \cdot 57 \pm 0.97$ \\
& 0.5 & $5 \cdot 33 \pm 1.03$ \\
pHMB/DTE & $0 \cdot 1 / 10$ & $99 \cdot 37 \pm 0 \cdot 72$ \\
\hline
\end{tabular}

absorption band at $278 \mathrm{~nm}$ (Fig. 2). Bacterial GOGATs presented $A_{278} / A_{443}$ values ranging from 4.8 in $A$. brasilense (Ratti et al., 1985) to about 20 in N. mediterranei (Mei \& Jiao, 1988).

Purified GOGAT was inhibited by atebrin and 2,2'dipyridyl, whereas salicylhydroxamate and $o$-phenanthroline inhibited only at high concentrations (Table 4). Sodium cyanide, sodium azide, NO, $\mathrm{CO}$ and acetylene showed no effects. The enzyme was also inactivated by a low concentration of thiol group reagents such as pHMB, the activity being almost completely recovered after incubation of inactivated enzyme with DTE (Table 5).

The GOGAT from $T$. thioparus was inhibited by reagents that would imply a catalytic role for both flavin and iron (Adachi \& Suzuki, 1977). The enzyme from $R$. capsulatus $\mathrm{E} 1 \mathrm{Fl}$ required high concentrations of these reagents to be completely inhibited (Table 4), thus
Table 6. Amino acid composition of GOGATs from various organisms

Samples of purified GOGAT from $R$. capsulatus E1F1 (about $0.3 \mathrm{mg}$ protein) were hydrolysed in evacuated glass tubes at $110^{\circ} \mathrm{C}$ for $24 \mathrm{~h}$ with $6 \mathrm{M}-\mathrm{HCl}$. After hydrolysis, the samples were evaporated in vacuum, derivatized with phenylisothiocyanate and analysed in a Waters HPLC according to the Waters PICO-TAG amino acid analysis system. Tryptophan was determined after alkaline hydrolysis with $4 \mathrm{M}-\mathrm{NaOH}$.

\begin{tabular}{lccc}
\hline \hline Residue & $R$. capsulatus & E. coli & A. brasilense $\ddagger$ \\
\hline Alanine & 206 & 176 & 176 \\
Arginine & 156 & 144 & 114 \\
Aspartic acid & 84 & 193 & 174 \\
Half-cystine & 59 & 38 & 38 \\
Glutamic acid & 37 & 190 & 203 \\
Glycine & 161 & 183 & 207 \\
Histidine & 58 & 41 & 44 \\
Isoleucine & 88 & 104 & 86 \\
Leucine & 162 & 170 & 159 \\
Lysine & 77 & 96 & 82 \\
Methionine & 90 & 47 & 36 \\
Phenylalanine & 54 & 75 & 55 \\
Proline & 109 & 96 & 65 \\
Serine & 117 & 111 & 90 \\
Threonine & 135 & 100 & 105 \\
Tryptophan & 9 & 20 & 13 \\
Tyrosine & 90 & 56 & 34 \\
Valine & 128 & 143 & 129 \\
\hline \hline
\end{tabular}

* Data from this study. Values are expressed as residues per $228 \mathrm{kDa}$ dimer.

$\dagger$ Data from Oliver et al. (1987). Values are expressed as residues per $218.5 \mathrm{kDa}$ dimer.

$\ddagger$ Data from Vanoni et al. (1990). Values are expressed as residues per $196.5 \mathrm{kDa}$ dimer, and were rounded to the nearest whole residue.

indicating that the prosthetic groups of GOGAT are not easily accessible to the chemical reagents used. By contrast, the strongly inactivating effect of pHMB implies that some -SH groups essential for enzyme activity and/or stability are probably more exposed.

GOGAT from $R$. capsulatus E1F1 contained an unusual amount of carboxylic and amidic amino acids, as well as of methionine and tyrosine. When compared with other GOGATs, a relatively high amount of cysteine residues $(0.24$ per $\mathrm{kDa})$ was found in the $R$. capsulatus E1F1 enzyme (Table 6; Oliver et al., 1987; Vanoni et al., 1990). GS, the first enzyme of the main ammonium assimilation pathway, has a very similar ratio $(0 \cdot 22$ cysteine residues per $\mathrm{kDa}$, see Caballero et al., 1985). Besides the role of cysteine in iron-sulphur clusters, this amino acid has been reported as a key residue in binding substrates of $E$. coli GOGAT (Mäntsälä \& Zalkin, $1976 b$; Gosset et al., 1989).

In $R$. capsulatus $\mathrm{E} 1 \mathrm{~F} 1$, apparent $K_{\mathrm{m}}$ values of GOGAT for 2-oxoglutarate $(15 \mu \mathrm{M})$ and NADPH $(20 \mu \mathrm{M})$ were of the same order as those described for other bacterial GOGATs (Yelton \& Yoch, 1981; Ratti et al., 1985). Non-hyperbolic saturation kinetics for L-Gln has been 


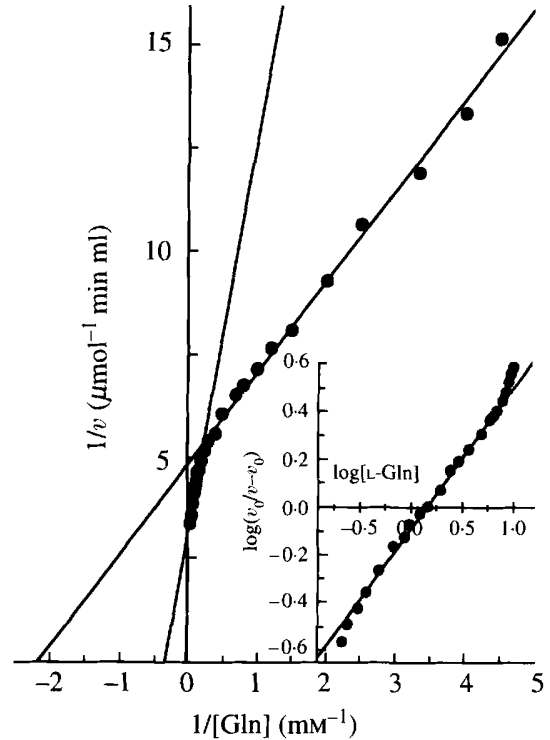

Fig. 4. Double reciprocal plots of initial velocity versus substrate concentration in the GOGAT reaction. Initial velocities (in $\mu \mathrm{mol} \mathrm{min}{ }^{-1}$ ) of purified GOGAT from $R$. capsulatus E1F1 were measured at the L-Gln concentrations indicated in the Figure. In each case, the concentrations of the other substrates were saturating. The inset shows the replot of the data according to the Hill representation. Each point represents the mean of four experiments.

Table 7. Effect of several compounds on the GOGAT activity from $R$. capsulatus EIFI

Enzyme activity was determined with pure enzyme preparations, as described in Methods, in the presence of the different metabolites at the indicated concentrations. Other L-amino acids tested were without effect. Specific activity of $100 \%$ corresponded to $20.5 \mathrm{U}$ (mg protein $)^{-1}$. Data represent the mean of four experiments.

\begin{tabular}{|c|c|c|}
\hline Addition & $\begin{array}{l}\text { Concn } \\
(\mathrm{mM})\end{array}$ & $\begin{array}{c}\text { Inhibition } \\
(\%)\end{array}$ \\
\hline \multirow[t]{2}{*}{ L-Asp } & 1 & $20 \cdot 40 \pm 1 \cdot 14$ \\
\hline & 10 & $37 \cdot 06 \pm 1 \cdot 17$ \\
\hline \multirow[t]{2}{*}{ Fumarate } & 1 & $17.64 \pm 1.67$ \\
\hline & 10 & $29.43+1.52$ \\
\hline \multirow[t]{2}{*}{ Isocitrate } & 1 & $14 \cdot 64 \pm 1 \cdot 16$ \\
\hline & 10 & $22 \cdot 17 \pm 2 \cdot 61$ \\
\hline \multirow[t]{2}{*}{ Oxaloacetate } & 1 & $17 \cdot 17 \pm 1.82$ \\
\hline & 10 & $27.45 \pm 1.38$ \\
\hline \multirow[t]{2}{*}{ ATP } & 1 & $0 \cdot 25 \pm 1.04$ \\
\hline & 10 & $37.83 \pm 1.33$ \\
\hline \multirow[t]{2}{*}{ ADP } & 1 & $24 \cdot 02 \pm 2 \cdot 16$ \\
\hline & 10 & $52.38 \pm 1.60$ \\
\hline \multirow[t]{2}{*}{ AMP } & 1 & $0.32 \pm 0.95$ \\
\hline & 10 & $35 \cdot 20 \pm 1.79$ \\
\hline \multirow[t]{2}{*}{ Azaserine } & 1 & $26 \cdot 78 \pm 1 \cdot 28$ \\
\hline & 10 & $90 \cdot 25 \pm 0.96$ \\
\hline
\end{tabular}

observed in GOGAT from $R$, capsulatus E1F1, whereas hyperbolic curves were observed for 2-oxoglutarate and NADPH. Non-hyperbolic kinetics has also been described in B. licheniformis (Schreier \& Bernlohr, 1984) and Bacillus megaterium (Hemmilä \& Mäntsälä, 1978) contrary to what was reported for the GOGAT from $A$. brasilense, which showed hyperbolic kinetics for LGln, NADPH and 2-oxoglutarate (Ratti et al., 1985). B. licheniformis and Rsp. rubrum enzymes also presented hyperbolic kinetics for L-Gln, but with low $K_{\mathrm{m}}$ values ( $65 \mu \mathrm{M}$ and $8 \mu \mathrm{M}$, respectively) (Schreier \& Bernlohr, 1984; Carlberg \& Nordlund, 1991). The two apparent $K_{\mathrm{m}}$ values for L-Gln ( 0.45 and $3.4 \mathrm{~mm})$ exhibited by GOGAT from $R$. capsulatus can be interpreted in terms of negative cooperativity as deduced from the Hill plot, the value of the Hill coefficient ( $h=0.5$; Fig. 4) and the concave form of the Scatchard curve (not shown). Negative cooperativity in GOGAT is not unexpected, taking into account that the enzyme forms spontaneously polymeric superaggregates which probably present several glutamine binding sites (at least one site per functional dimer). Taking into account that the $\mathrm{L}-\mathrm{Gln}$ concentration inside these cells is probably subjected to rapid and strong fluctuations due to the regulation of GS activity by the adenylylation cascade (Caballero et al., 1985), kinetic regulation of GOGAT by L-GIn could not be discarded. However, the Scatchard plot is only a qualitative approach to studies on negative cooperativity (Dahlquist, 1978), therefore a concave form of the plot due to site heterogeneity caused by different aggregation states cannot be ruled out in our case.

We have not observed a significant inhibition of GOGAT by amino and carboxylic acids (Table 7), at least in the physiological intracellular concentrations of these compounds in $R$. capsulatus E1F1, which were always of the micromolar range (results not shown). Nevertheless, the enzyme was $64 \%$ inhibited by $1 \mathrm{~mm}$ MSX. GOGAT from the phototrophic bacterium Rhodopseudomonas acidophila was also strongly inhibited by this glutamate analogue (Herbert et al., 1978). The inhibition of GOGAT by high concentrations of amino and carboxylic acids has been reported in other bacteria (Adachi \& Suzuki, 1977; Mei \& Jiao, 1988; Ertan, 1992).

GOGAT from $R$. capsulatus E1F1 was strongly inhibited by the products of the reaction, L-Glu and $\mathrm{NADP}^{+}$, which were competitive inhibitors with respect to L-GIn and NADPH, respectively, as deduced from the corresponding Cornish-Bowden plots. From the Lineweaver-Burk plots, $K_{\mathrm{i}}$ values of $10 \mathrm{~mm}-\mathrm{L}-\mathrm{Glu}$ and $0 \cdot 1 \mathrm{mM}^{-\mathrm{NADP}^{+}}{ }^{+}$were calculated. This result is consistent with MSX inhibition reported above. Product inhibition of GOGAT in $R$. capsulatus could also have physiological significance, especially in the case of the competitive inhibition of $\mathrm{NADP}^{+}$, which gave a low $K_{\mathrm{i}}$ value $(0 \cdot 1 \mathrm{~mm})$. Inhibition of GOGAT by L-Glu and NADP ${ }^{+}$ has also been reported in other bacterial enzymes (Sung et al., 1984; Ratti et al., 1985; Matsuoka \& Kimura, 1986). Since we have not measured the intracellular concentrations of $\mathrm{NADP}^{+}$and NADPH under different 
metabolic conditions, we cannot conclude that the $\mathrm{NADP}^{+} / \mathrm{NADPH}$ ratio has an in vivo regulatory significance in the GOGAT activity of $R$. capsulatus E1F1.

The authors wish to thank Professors Drs I. Nuñez de Castro and C. Gutiérrez for their helpful advice and also Dr L. Pérez (CSIC, El Zaidín, Granada) for amino acid analysis. The financial support of CICYT (Spain, Grant PB89 0336) and the Alexander von Humboldt Foundation (Germany) are also gratefully acknowledged. One of us (M.I.I.) is a recipient of a fellowship from the Junta de Andalucia (Spain).

\section{References}

ADACHI, K. \& SuzuKI, I. (1977). Purification and properties of glutamate synthase from Thiobacillus thioparus. Journal of Bacteriology 129, 1173-1182.

ALEF, K. \& ZUMFT, W. G. (1981). Regulatory properties of glutamine synthetase from the nitrogen-fixing phototrophic bacterium Rhodopseudomonas palustris. Zeitschrift für Naturforschung 36, 784-789.

Avila, C., Botella, J. R., Cánovas, F. M., NúÑez de Castro, I. \& VALPUESTA, V. (1987). Different characteristics of the two glutamate synthases in the green leaves of Lycopersicon esculentum. Plant Physiology 85, 1036-1039.

BEINERT, H. (1983). Semi-micro methods for analysis of labile sulfide and of labile sulfide plus sulfane sulfur in unusually stable iron-sulfur proteins. Analytical Biochemistry 131, 373-378.

BRADFORD, M. M. (1976). A rapid and sensitive method for the quantitation of microgram quantities of protein utilizing the principle of protein-dye binding. Analytical Biochemistry 72, 248-254.

Brewer, J. M., Pesce, A. J. \& Spencer, T. E. (1974). Ultracentrifugation. In Experimental Techniques in Biochemistry, pp. 161-215. Edited by J. M. Brewer, A. J. Pesce \& R. B. Ashworth. Englewood Cliffs, NJ: Prentice-Hall.

Caballero, F. J., Cejudo, F. J., Florencio, F. J., Cárdenas, J. \& Castillo, F. (1985). Molecular and regulatory properties of glutamine synthetase from the phototrophic bacterium Rhodopseudomonas capsulata E1 F1. Journal of Bacteriology 162, 804-809.

Caballero, F. J., Cárdenas, J. \& Castillo, F. (1987). Involvement of sulphydryl groups in glutamine synthetase activity from Rhodobacter capsulatus E1F1. FEMS Microbiology Letters 41, 7-11.

Caballero, F. J., Cárdenas, J. \& Castillo, F. (1989a). Purification and properties of L-alanine dehydrogenase of the phototrophic bacterium Rhodobacter capsulatus E1F1. Journal of Bacteriology 171, 3205-3210.

Caballero, F. J., Igeño, I., Cárdenas, J. \& Castillo, F. (1989b) Regulation of reduced nitrogen assimilation in Rhodobacter capsulatus E1F1. Archives of Microbiology 152, 508-511.

CARlberG, I. \& NoRdlund, S. (1991). Purification and partial characterization of glutamate synthase from Rhodospirillum rubrum grown under nitrogen-fixing conditions. Biochemical Journal 279 $151-154$.

Castaño, I., Bastarrachea, F. \& Covarrubias, A. A. (1988). git BDF operon of Escherichia coli. Journal of Bacteriology 170, 821-827.

Castillo, F., Moreno-Vivián, C., Igeño, M. I. \& Caballero, F. J. (1991). Catabolismo de aminoácidos en Rhodobacter capsulatus E1F1. In I Reunion de Biologia Molecular de Plantas, pp. 161-165. Edited by G. Nicolás \& B. Sabater. Salamanca, Spain: Publicaciones de la Universidad de Salamanca.

DahlQuist, F. W. (1978). The meaning of Scatchard and Hill plots. Methods in Enzymology 48, 270-299.

DoEG, K. A. \& Ziegler, D. M. (1962). Simplified methods for the estimation of iron in mitochondria and submitochondrial fractions. Archives of Biochemistry and Biophysics 97, 37-40.

ERTAN, H. (1992). Some properties of glutamate dehydrogenase, glutamine synthetase and glutamate synthase from Corynebacterium callunae. Archives of Microbiology 158, 35-41.

Galván, F., Márquez, A. J. \& Vega, J. M. (1984). Purification and molecular properties of ferredoxin-glutamate synthase from Chlamydomonas reinhardii. Planta 162, 180-187.
Gosset, G., Merino, E., Recillas, F., Oliver, G., Becerril, B. \& Bolivar, F. (1989). Amino acid sequence analysis of the glutamate synthase enzyme from Escherichia coli K-12. Protein Sequences \& Data Analysis 2, 9-16.

Hemmilä, I. A. \& MäntsäLä, P. I. (1978). Purification and properties of glutamate synthase and glutamate dehydrogenase from Bacillus megaterium. Biochemical Journal 173, 45-52.

Herbert, R. A., Siefert, E. \& Pfennig, N. (1978). Nitrogen assimilation in Rhodopseudomonas acidophila. Archives of Microbiology $119,1-5$.

JOHANSSON, B. C. \& GEST, H. (1976). Inorganic nitrogen assimilation by the photosynthetic bacterium Rhodopseudomonas capsulata. Journal of Bacteriology 128, 683-688.

LAEMMLI, U.K. (1970). Cleavage of structural proteins during the assembly of the head of bacteriophage T4. Nature, London 227, 680-685.

LEA, P. J. \& MifLin, B. J. (1975). The occurrence of glutamate synthase in algae. Biochemical and Biophysical Research Communications 64, 856-862.

Madigan, M. \& Cox, S. S. (1982). Nitrogen metabolism in Rhodopseudomonas globiformis. Archives of Microbiology 133, 6-10.

Madkour, M. A., Smith, L. T. \& Smith, G. M. (1990). Preferential osmolyte accumulation: a mechanism of osmotic stress adaptation in diazotrophic bacteria. Applied and Environmental Microbiology 56, 2876-2881.

MÄNTSÄLÄ, P. \& ZALKIN, H. (1976a). Active subunits of Escherichia coli glutamate synthase. Journal of Bacteriology 126, 539-541.

MÄNTSÄLÄ, P. \& ZALKIN, H. (1976b). Glutamate synthase: properties of the glutamine-dependent activity. Journal of Biological Chemistry 251, 3294-3299.

Márquez, A. J., Galván, F. \& Vega, J. M. (1984). Purification and characterization of the NADH-glutamate synthase from Chlamydomonas reinhardii. Plant Science Letters 34, 305-314.

Martin, R. G. \& Ames, B. N. (1961). A method of determining the sedimentation behavior of enzymes: application to protein mixtures. Journal of Biological Chemistry 236, 1372-1379.

MatsuoKa, K. \& Kimura, K. (1986). Glutamate synthase from Bacillus subtilis PCI 219. Journal of Biochemistry 99, 1087-1100.

MeI, B. \& JiaO, R. (1988). Purification and properties of glutamate synthase from Nocardia mediterranei. Journal of Bacteriology 170, 1940-1944.

MifLIN, B. J. \& LEA, P. J. (1976). The pathway of nitrogen assimilation in plants. Phytochemistry 15, 873-885.

Miller, R. E. \& Stadtman, E. R. (1972). Glutamate synthase from Escherichia coli. Iron sulfide flavoprotein. Journal of Biological Chemistry 247, 7407-7419.

Moreno-Vivián, C., Cejudo, F. J., Cárdenas, J. \& Castillo, F. (1983). Ammonia assimilation pathways in Rhodopseudomonas capsulata E1F1. Archives of Microbiology 136, 147-151.

Moreno-Vivián, C., Caballero, F. J., Martínez-Luque, M., CárDENAS, J. \& CASTILlo, F. (1990). Regulation of inorganic nitrogen metabolism in the phototrophic bacterium Rhodobacter capsulatus E1F1. In Inorganic Nitrogen in Plants and Microorganisms, pp. 145150. Edited by W. R. Ullrich, C. Rigano, A. Fuggi \& P. J. Aparicio. Berlin: Springer-Verlag.

Nordlund, S., Kanemoto, R. H., Murell, S. A. \& Ludden, P. W. (1985). Properties and regulation of glutamine synthetase from Rhodospirillum rubrum. Journal of Bacteriology 161, 13-17.

Oliver, G., Gosset, G., Sánchez-Pescador, R., Lozoya, E., Ku, L. M., Flores, N., Becerril, B., Valle, F. \& Bolivar, F. (1987). Determination of the nucleotide sequence for the glutamate synthase structural genes of Escherichia coli K-12. Gene 60, 1-11.

PundaK, S. \& EISENBERG, M. (1981). Structure and activity of malate dehydrogenase from the extreme halophilic bacteria of the Dead Sea. European Journal of Biochemistry 118, 463-470.

Ratti, S., Curti, B., Zanetti, G. \& Galli, E. (1985). Purification and characterization of glutamate synthase from Azospirillum brasilense. Journal of Bacteriology 163, 724-729.

Ratti, S., Vanoni, M. A., Grandori, R., Zanetti, G. \& Curti, B. (1987). Kinetic studies on glutamate synthase from Azospirillum brasilense. In Flavins and Flavoproteins 1987, pp. 385-389. Edited by D. E. Edmondson \& D. B. McCormick. Berlin: Walter de Gruyter. 
Romero, F., Caballero, F. J., Castillo, F. \& Roldán, J. M. (1985). Immunoelectrophoretic approach to the metabolic regulation of glutamine synthetase in Rhodopseudomonas capsulata E1F1: role of glutamine. Archives of Microbiology 143, 111-116.

SCHREIER, H. J. \& BERNLOHR, R. W. (1984). Purification and properties of glutamate synthase from Bacillus licheniformis. Journal of Bacteriology 160, 591-599.

Siegel, L. M. \& MonTy, K. J. (1966). Determination of molecular weights and frictional ratios of proteins in impure systems by use of gel filtration and density gradient centrifugation. Application to crude preparations of sulfite and hydroxylamine reductase. Biochimica et Biophysica Acta 112, 346-362.

Singhal, R. K., Krishnan, I. S. \& Dua, R. D. (1989). Stabilization, purification, and characterization of glutamate synthase from Clostridium pasteurianum. Biochemistry 28, 7928-7935.

Smith, P. K., Krohn, R. I., Hermanson, G. T., Mallia, A. K., Gartner, F. H., Provenzano, M. D., Fujimoto, E. K., Goeke, N. M., OLSON, B. J. \& KLENK, D. C. (1985). Measurement of protein using bicinchoninic acid. Analytical Biochemistry 150, 76-85.

Stewart, G. R., ManN, A. F. \& Fentem, P. A. (1980). Glutamate synthase. In The Biochemistry of Plants, vol. 5, pp. 309-327. Edited by B. J. Miflin. New York: Academic Press.

Sung, H. C., Tachiki, T., Kumagai, H. \& Tochikura, T. (1984). Properties of glutamate synthase from Brevibacterium flavum. Journal of Fermentation Technology 62, 569-575.

Tempest, D. W., Meers, J. L. \& Brown, C. M. (1970). Synthesis of glutamate in Aerobacter aerogenes by a hitherto unknown route. Biochemical Journal 117, 405-407.
Trotta, P. P., Platzer, K. E. B., Haschemeyer, R. H. \& Meister, A (1974). Glutamine-binding subunit of glutamate synthase and partial reactions catalyzed by this glutamine amidotransferase. Proceedings of the National Academy of Sciences of the United States of America 71, 4607-4611.

Vanoni, M. A., Negri, A., Zanetti, G., Ronchi, S. \& Curti, B. (1990). Structural studies on the subunits of glutamate synthase from Azospirillum brasilense. Biochimica et Biophysica Acta 1039, 374-377.

Vanoni, M. A., Edmondson, D. E., Rescigno, M., Zanetti, G. \& CURTI, B. (1991a). Mechanistic studies on Azospirillum brasilense glutamate synthase. Biochemistry 30, 11478-11484.

Vanoni, M. A., Nuzzi, L., Rescigno, M., Zanetti, G. \& Curti, B. $(1991 b)$. The kinetic mechanism of the reactions catalyzed by the glutamate synthetase from Azospirillum brasilense. European Journal of Biochemistry 202, 181-189.

VANONi, M. A., Edmondson, D. E., ZanetTI, G. \& Curti, B. (1992). Characterization of the flavins and the iron-sulfur centers of glutamate synthase from Azospirillum brasilense by absorption, circular dichroism, and electron paramagnetic resonance spectroscopies. Biochemistry 31, 4613-4623.

WANG, C. C. \& RAPER, I. R. (1970). Isozyme patterns and sexual morphogenesis in Schizophilum. Proceedings of the National Academy of Sciences of the United States of America 66, 882-889.

WOESE, C. R. (1987). Bacterial evolution. Microbiological Reviews 51, 221-271

Yelton, M. M. \& Yoch, D. C. (1981). Nitrogen metabolism in Rhodospirillum rubrum: characterization of glutamate synthase. Journal of General Microbiology 123, 335-342. 